\title{
Servikal nekrotizan fasiit: Beş olgu sunumu
}

\author{
Cervical necrotising fasciitis: Five case reports
}

Ümit Yılmaz@, Aylin Gül@, Vefa Kınış®, İsmail Topçu®

Dicle Üniversitesi Tıp Fakültesi, Kulak Burun Boğaz Anabilim Dalı, Diyarbakır, Türkiye

\begin{abstract}
$\ddot{O} Z$
Nekrotizan fasiit yüzeyel fasya ve deri altı dokuyu tutan, hızlı ilerleyen ve hayatı tehdit eden yumuşak doku enfeksiyonudur. Morbidite ve mortalite riski yüksek olup baş ve boyun bölgesinde nadir görülür. Servikal nekrotizan fasiitin tedavisi intravenöz antibiyotik terapisini ve acil cerrahi debridmanı içerir. Bu yazıda, servikal nekrotizan fasiit tanılı beş olgu sunuldu.
\end{abstract}

Anahtar sözcükler: Boyun; nekrotizan fasiit; tedavi.

Nekrotizan fasiit ilk olarak 1952 y1lında Wilson tarafından tanımlanmıştır. Bu tanıma göre, nadir görülen, hızlı bir şekilde ilerleyen, ölümcül seyreden, cilt ve cilt altı dokusunu tutan yumuşak doku enfeksiyonudur. ${ }^{[1]}$ Nekrotizan fasiit genellikle ekstremite, abdominal duvar ve perineumu tutar. Baş ve boyun bölgesinde nadir olarak görülür. ${ }^{[2]}$ Servikal nekrotizan fasiit agresif ve ölümcül seyreder. Diş enfeksiyonları ve farenks kökenli enfeksiyonlar sonrası daha sıklıkla görülmektedir. Servikal nekrotizan fasiit önemli mortibite ve mortalite nedenidir. Mortalite oranı \%40 ile \%76 arasında değişmektedir. ${ }^{[3]}$ $\mathrm{Bu}$ durum hastalığın agresif bir seyir göstermesine ve geciken cerrahi müdahaleye bağlanmaktadır.

Nekrotizan fasiit hastalarının birçoğunda ileri yaş, akut böbrek yetmezliği, kronik böbrek yetmezliği, diabetes mellitus, intravenöz ilaç kullanımı, alkolizm, malignite, malnutrisyon gibi immün sistemi zayıflatan durumlar mevcuttur. ${ }^{[4]}$ Erken tanı konulup hızlı müdahale edilir ve cerrahi tedavi uygulanırsa sonuç yüz güldürücü olabilir.

\begin{abstract}
Necrotizing fasciitis is a rapidly progressive and life-threatening soft-tissue infection that affects superficial fascia and subcutaneous tissue. With high risk of morbidity and mortality, it is rarely seen in the head and neck region. Treatment of cervical necrotizing fasciitis includes intravenous antibiotic therapy and emergency surgical debridement. In this article, we present five cases with a diagnosis of cervical necrotizing fasciitis.
\end{abstract}

Keywords: Neck; necrotizing fasciitis; treatment.

$\mathrm{Bu}$ çalı̧̧mada, kliniğimizde yakın dönemde takip ettiğimiz servikal nekrotizan fasiitli beş olguyu sunmayı ve literatürü gözden geçirerek tartışmayı amaçladık.

\section{OLGU SUNUMU}

Makalede sunulan servikal nekrotizan fasiit tanısı konulan hasta veya hasta yakınlarından bilgilendirilmiş onam formu alınmıştır.

Olgu 1- Altmış yaşında erkek hasta boyunda şişlik, ağrı, yutma güçlüğü şikayetleri ile kulak burun boğaz polikliniğine başvurdu. Hastanın öyküsünden 10 gün önce boğazına kı1çık battığ 1 ve kılçı̆̆ 1 kendi imkanları ile çıkardığı ancak olaydan iki gün sonra yutma güçlüğü ve ağrı şikayetlerinin başladı̆̆ 1 ve hastanın diabetes mellitus tanısı olduğu halde ilaçlarını düzenli kullanmadığ 1 öğrenildi. Fizik muayenesinde, submental ve iki taraflı submandibüler bölgeyi içine alan, hassas, hiperemik şişliği vardı. Hastanın laboratuvar sonuçlarında, beyaz küre

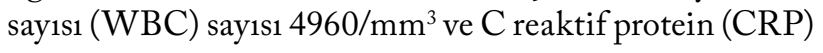

Geliş tarihi: 26 Mart 2018 Kabul tarihi: 07 Haziran 2018

İletişim adresi: Dr. Aylin Gül. Dicle Üniversitesi Tıp Fakültesi, Kulak Burun Boğaz Anabilim Dalı, 21280 Diyarbakır, Türkiye.

Tel: 0412 - 2488001 / 4543 e-posta: mdaylingul@gmail.com 
düzeyi $9.57 \mathrm{mg} / \mathrm{dL}$ olarak izlendi. Hastanın kontrastlı boyun tomografisinde iki taraflı paraözofageal, paratrakeal ve tüm boyun fasiyal planlar boyunca superiora doğru uzanım gösteren hava değerleri izlendi (Şekil 1). Toraks bilgisayarlı tomografi (BT)'sinde de alt boyun kesitlerinde, toraks duvarı yumuşak dokuları arasında ve posterior mediastende özofagus çevresinde hava değerleri izlendi. Hasta fizik muayene ve görüntüleme sonuçları doğrultusunda servikal nekrotizan fasiit, mediastinit ve özofagus rüptürü ön tanılarıyla göğüs cerrahisi kliniği ile birlikte acil ameliyata alındı. Ameliyat sırasında boyunda tüm fasiyal planların nekroze olduğu, özofagusun sağ lateralde açık olduğu görüldü ve nekrotik dokular debride edildi (Şekil 2). Trakeotomi açıldı. Hastanın ameliyat sonrası süreçte, yoğun bakımda, tarafımızca oksijenli su, rifampisin ve furacin pomadlarla yaklaşık 40 gün, günde iki defa olmak üzere açık pansumanları yapıldı, nekroze dokular debride edildi. Hastaya vankomisin $3 \times 1$, meronem $3 \times 1$ antibiyotik tedavisi başland. Antibiyoterapiye

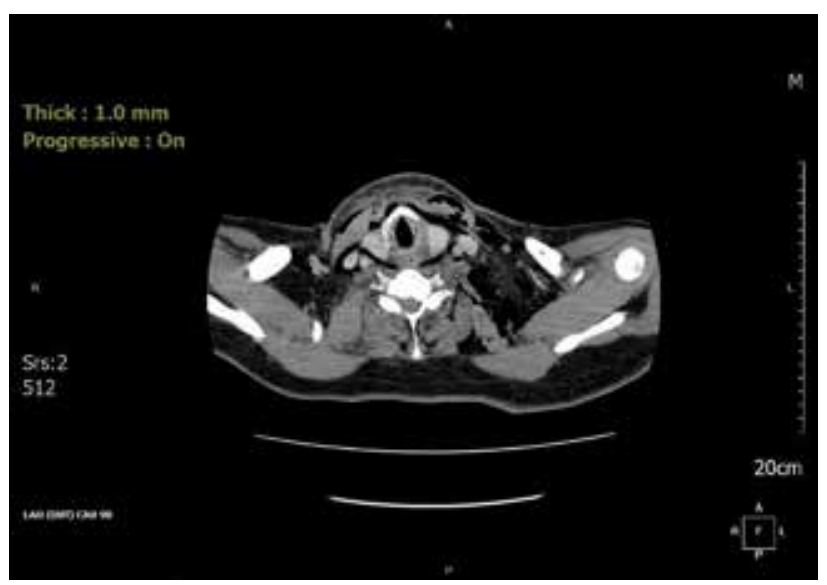

Şekil 1. Aksiyal kesit kontrastlı boyun tomografi incelemesinde tüm boyun fasiyal planlardaki hava değerleri.

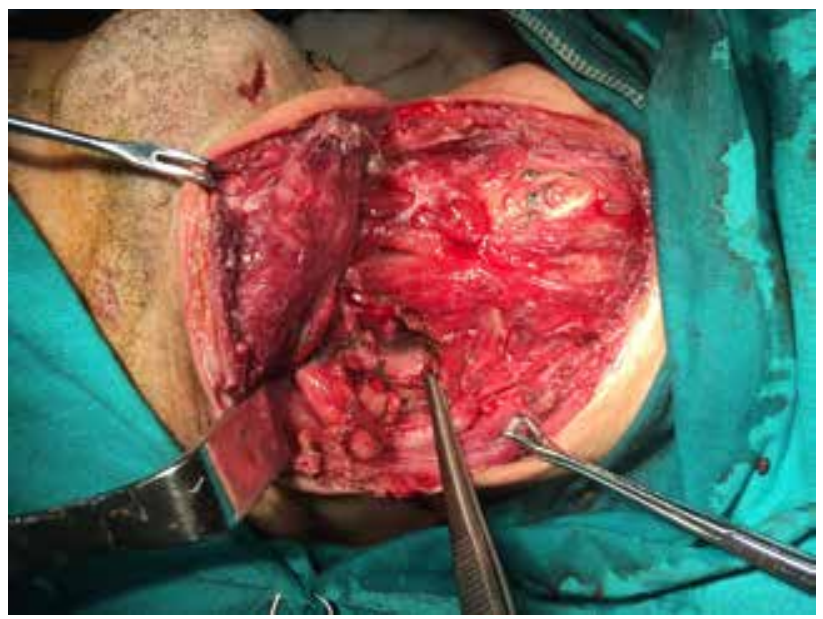

Şekil 2. Sağ lateral yerleşimli özofagus açıklığı. rağmen ateşi devam eden ve CRP'si yüksek seyreden hasta enfeksiyon hastalıklarına konsülte edildi, kan kültüründe enterococcus faecium üremesi oldu. Daptomisin $1 \times 500 \mathrm{mg}$ ve eraxis (anidulafungin) $1 \times 1$ tedavisi başland. Takipleri yapılan hastanın genel durumunun düzelmesi ve kontrastli boyun BT'sinde apse görünümün gerilemesi ve mediastinit bulgularının ortadan kalkması üzerine, yatışının 60. gününde trakeotomisi kapatılarak taburcu edildi.

Olgu 2- Otuz yaşında erkek hasta, boyunda şişlik, ağrı, yutmakta güçlük, ağzını açamama ve ateş şikayetleri ile kulak burun boğaz polikliniğine başvurdu. Hastanın öyküsünden, beş gün önce başlayan diş ağrisı olduğu öğrenildi. Fizik muayenesinde, sağ submandibüler ve submental bölgeyi kaplayan, ağrıli, sert kıvamda, fluktuasyon vermeyen şişliği ve belirgin trismusu vard. Laboratuar sonuçlarında WBC $20120 / \mathrm{mm}^{3}$ ve CRP $16.84 \mathrm{mg} / \mathrm{dL}$ olarak izlendi. Kontrastlı boyun BT'sinde iki taraflı ağ 1 z tabanında geniohyoid ve mylohyoid kasları arasında sağda yaklaşık $30 \times 18 \mathrm{~mm}$ boyutunda yer yer lokülasyon gösteren sıvı koleksiyonları izlendi (Şekil 3). Boyun cilt-ciltaltı dokuları, inferiorda toraks girimine kadar uzanan alanlarda yaygın infiltratif görünümler izlenmekteydi. Hasta derin boyun enfeksiyonu ön tan1siyla yatırıld 1 ve seftriakson $1 \mathrm{gr} 2 \times 1$ ve ornidazol $500 \mathrm{mg}$ $3 \times 1$ antibiyotik tedavisi başlandı. Solunum sıkıntısı olan hasta ameliyata alındı ve trakeotomi açıldı. Hastanın ağız içi fistülize olan yerden fistül ağzı genişletildi ve apse boşaltıldı. Hastanın alınan apse kültürlerinde klebsiella oxytoca ve klebsiella pneumoniae üredi. Enfeksiyon kliniğgi görüşü üzerine hastaya meropenem $3 \times 1$ ve vankomi$\sin 2 \times 1$ başlandı. Hastanın takiplerinin 25 . gününde ağız açıklığının tamamen düzelmesi, çekilen kontrol

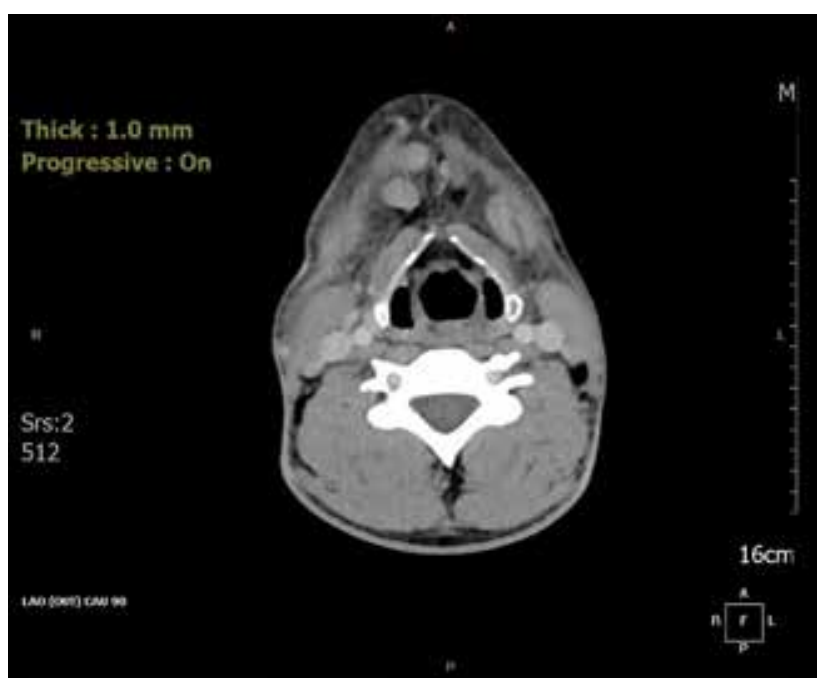

Şekil 3. Aksiyal kesit kontrastlı boyun tomografi incelemesinde ağız tabanındaki yer yer lokülasyon gösteren sıvı koleksiyonları. 
kontrastlı boyun BT'sinde apsenin ve enfeksiyonun gerilemesi ve genel durumunun düzelmesi üzerine trakeotomisi kapat1larak taburcu edildi.

Olgu 3- Altmış bir yaşında kadın hasta 10 gündür var olan boyunda şişlik, ağrı ve yutma güçlüğü şikayetleriyle kliniğimize başvurdu. Hastanın özgeçmişinde 10 yıldır diabetes mellitus ve hipertansiyon hastası olduğu, beş yıl önce geçirilmiş baypas öyküsü olduğu öğrenildi. Fizik muayenesinde, submental ve iki taraflı submandibüler alanlara yaygın, hassas ve ağrılı şişlik vardı. Laboratuvar

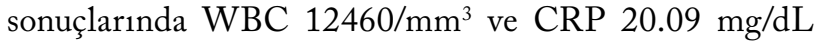
olarak izlendi. Boyun manyetik rezonans görüntülemesinde, orta hat mylohyoid kas düzeyinde ve iki taraflı submandibüler alanda en geniş yerinde yaklaşık $5 \times 3 \mathrm{~cm}$ boyutlarında heterojen yoğun intensitede ve içerisinde hava değerleri bulunan yoğun kontrastlama gösteren sıvı koleksiyon izlendi (Şekil 4). Sıvı koleksiyonu inferiorda tiroid bezine kadar uzaniyordu. Hasta derin boyun enfeksiyonu ön tanısıyla yatırıldı. Hastanın genel durumu kötüydü ve oral alım bozukluğu vardı. Kan şeker takip değerleri düzenli olmayan hastaya parenteral seftriakson $2 \times 1$ gr ve ornidazol $3 \times 500 \mathrm{mg}$ antibiyotik tedavisi başlandı. Hastanın solunum sıkıntısı olması üzerine ameliyata alındı, ameliyat sırasında dil kökü ve vallekulanın oldukça nekrotik olduğu, epiglot ve aritenoidlerin belirgin ödemli olduğu izlendi. Hastaya trakeotomi açıldı. Ardından sağ boyun seviye $1-2$ ve seviye 6 'da apse ve nekrotik dokular debride edildi ve günlük furacinli ve rifocinli pansuman için açık bırakıldı. Hastaya ameliyat sonrası kan kültürlerinde enterococcus faecium üremesi üzerine enfeksiyon uzmanının görüşüne göre tazobaktam+piperacilin $4.5 \mathrm{gr} 3 \times 1$ ve ameliyat alanında alınan doku kültüründe mucor düşündüren lezyonlar izlenmesi üzerine amfotericin $5 \mathrm{mg} / \mathrm{kg}$ tedavi başlandı. Hastaya günlük oksijenli su, rifamisin ve furacinli yaklaşık 30 gün açık pansuman yapıldı. Hasta yatışının 10 . gününde debridman amaçlı tekrar ameliyata alındı cilt

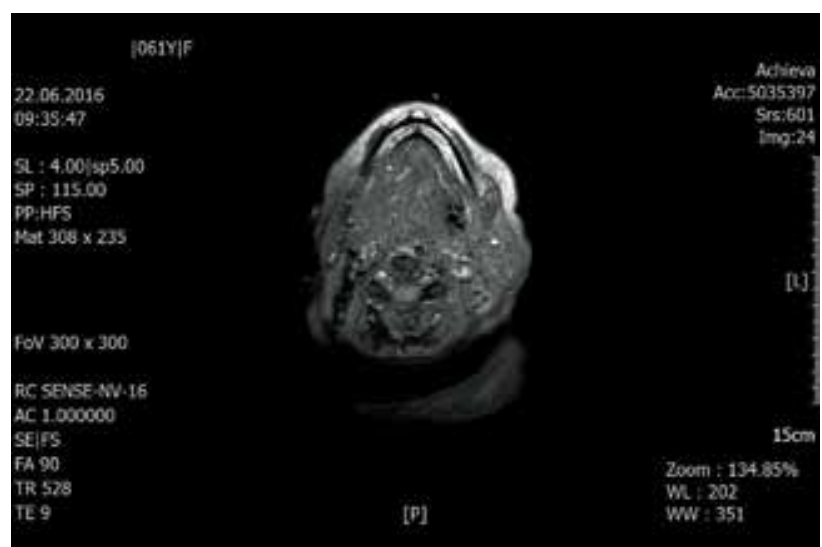

Şekil 4. Aksiyel kesit manyetik rezonans görüntülemede submandibüler alandaki hava değerleri. altındaki nekrotik dokular temizlendi. Hastanın takiplerinde genel durumunun düzelmesi, ağı açıklığının sağlanması, oral alımının düzelmesi ve çekilen kontrol kontrastlı boyun BT'sinde de apsenin gerilediğinin görülmesi üzerine trakeotomisi kapatılarak taburcu edildi.

Olgu 4- Yirmi altı yaşında kadın hasta, ateş, boğaz ağrıs1, nefes darlı̆̆1, göğüs ağrisı ve yutmakta güçlük şikayetleriyle kulak burun boğaz polikliniğine başvurdu. Hasta genel durumunun gittikçe kötüleşmesi üzerine acil servise sevk edildi. Acil serviste muayenesi yapılan hastanın genel durumu kötü, hipotansif, taşikardik ve dispneik idi, ateşi 39 dereceydi. Hastanın tip 1 diabetes mellitus olduğu öğrenildi. Kulak burun boğaz muayenesinde boyunda yaygın ağrılı şişliği vardı. Laboratuvar sonuçlarında WBC $2290 / \mathrm{mm}^{3}$ ve CRP $24.81 \mathrm{mg} / \mathrm{dL}$ olarak izlendi. Kontrastl1 toraks ve boyun BT'sinde alt boyun kesitlerinde yumuşak dokular arasinda, paratrakeal bölgede ve mediastende yaygin hava yoğunlukları izlendi (Şekil 5). Hasta derin boyun enfeksiyonu ve mediastinit ön tanısiyla yatırıld 1 ve debridman amaçlı göğüs cerrahisi ile birlikte acil ameliyata alınd. Ameliyatta alt boyunda ve paratrakeal bölgedeki tüm fasyaları saran nekrotik dokular debride edildi. Sol akciğer üst lobunda yaygın yapışık enfekte dokular izlendi ve debride edildi. Süperior, anterior ve posteriordaki pariyetal plevra diseke edilerek içerisindeki ampiyem boşaltıldı. Hastaya uygulanan tüp torakostomiden $500 \mathrm{~mL}$ ampiyem boşaltıld. Hasta ameliyat sonrası yoğun bakımda entübe şekilde takip edildi. Günlük rifocin, furacin ve oksijenli su ile pansumanları yapıldı. Hastaya enfeksiyon hastalıklarının görüşüne göre vankomisin 1 gr $2 \times 1$ ve meropenem 1 gr $2 \times 1$ antibiyotik tedavisi başlandı. Yoğun tedaviye rağmen metabolik durumunda düzelme olmayan ve gittikçe kötüleşen hasta ameliyat sonrası ikinci gününde iki kez kardiyak arrest geçirdi. Kardiyopulmoner resüsitasyona yanıt vermeyen hasta kaybedildi.

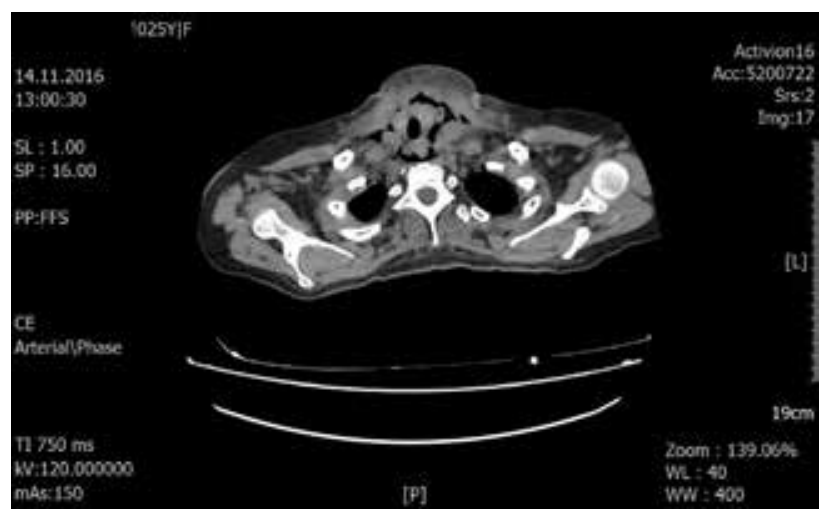

Şekil 5. Aksiyal kesit kontrastlı boyun bilgisayarlı tomografi incelemesinde paratrakeal bölgede ve mediastende yaygin hava yoğunlukları. 


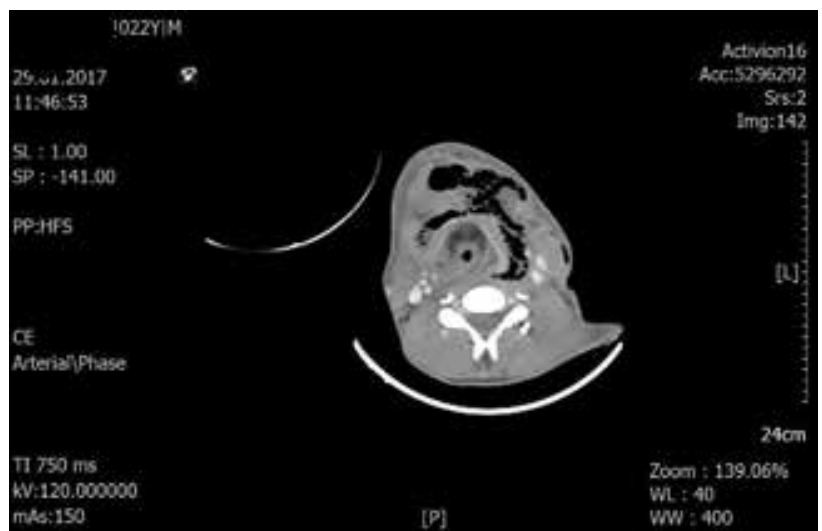

Şekil 6. Aksiyal kesit kontrastlı boyun bilgisayarlı tomografi incelemesinde boyun fasiyal planlardaki hava değerleri.

Olgu 5- Yirmi üç yaşında erkek hasta solunum sıkıntısı nedeni ile acil servisimize başvurdu. Hastanın öyküsünden 15 gün önce başlayan diş ağrısı sonrasında boyunda şişlik oluştuğu, diş merkezde şişlik bölgesinden drenaj yapıldığ 1 ve antibiyotik tedavisi başlandığ 1 ancak şikayetlerinde artma olması üzerine hastanın acil servisimize başvurduğu öğrenildi Fizik muayenesinde submental ve iki taraflı submandibüler bölgede sert kıvamda olmak üzere tüm boyunda yaygın şişlik, kızarıklık ve hassasiyeti vardı. Orofarenks muayenesinde sağ birinci molar diş hizasında belirgin hassasiyet, şişlik ve kızar1kl1k görüldü. Kontrastlı boyun BT'sinde, toraks girimi düzeyinden başlayarak karotis mesafesinde, iki tarafli submandibüler alanlarda ve parafarengeal alanlarda yaygın fasiyal planlarda hava değerleri ve yer yer yumuşak doku yoğunlukları vardı. İki taraflı submandibüler alanlarda, nazofarenks posterior duvarda ve diğer boyun yağlı planlarda yaygın infiltratif görünümler dikkati çekmekte idi. Bu düzeylerde orofarengeal ve nazofarenks hava kolonu ileri derecede daralmıştı (Şekil 6). Hastanın laboratuvar bulgularında WBC $32000 / \mathrm{mm}^{3}$ ve CRP $11.1 \mathrm{mg} / \mathrm{dL}$ olarak izlendi. Derin boyun enfeksiyonu ön tanısı ile yatışı yapılan hasta acil şartlarında ameliyata alındı ve trakeotomi açıldı. Cilt altından yoğun püy drene olduğu görüldü ve cilt altı dokular ve boyun strep kasları ve iki taraflı sternokleidomastoid kası medialine kadar yoğun nekrotik dokular izlendi. Nekroze alanlar yukarıda ağız tabanından supraklaviküler bölgeye kadar uzanımı izlendi ve tüm bu alanlar debride edildi. Hasta yoğun bakım şartlarında takip edildi ve günlük rifocin ve furacin ile yaklaşık 20 gün açık pansumanları yapıld. Hastaya enfeksiyon hastalıklarının önerisi ile geniş spektrumlu antibiyoterapi başland. Hastanın ameliyat sonrası 20. gününde nekroze alanların tamamen nekrozdan ve enfeksiyondan temizlendiği izlendi. Hastanın kulak burun boğaz kliniği açısından, pansuman yerinin iyi olması, hastanın ek nörolojik şikayetlerinin olması nedeniyle nöroloji kliniğine devir edildi. Hastanın hipoksik ensefalopati nedeni ile nöroloji yoğun bakımda yatı̧ı devam etmektedir.

\section{TARTIŞMA}

Servikal nekrotizan fasiit, patojen bakterilerin boyunda ve fasya planında geniş doku nekrozları oluşturarak meydana getirdiği yumuşak doku enfeksiyonudur. Tedavi edilmemiş servikal nekrotizan fasiit olguları kafa tabanına ve mediastinuma yayılabilir, sepsise veya multi organ yetmezliğine neden olabilir ve ölümle sonuçlanabilir. ${ }^{[3,5]}$

Servikal nekrotizan fasiit erkeklerde daha $\mathrm{s} 1 \mathrm{k}$ görülür. ${ }^{[2]}$ En sık dental patolojiler kaynaklı olup bunu parafarengeal ve peritonsiller bölgenin enfeksiyonları takip eder. Dental patolojilerde enfeksiyonun nedeni genellikle mandibuladaki ikinci ve üçüncü molar dişlerdir. ${ }^{[6]} \mathrm{Bu}$ dişlerin apeksleri milohyoid kasının mandibulaya yapışma yerinin altına uzanır. Bu nedenle bu dişlerden kaynaklanan enfeksiyonlar kolaylıkla submandibüler bölgeye ulaşır. Sonrasında enfeksiyon yukarıda kafa tabanına ve aşağ yebilir. Olgularımızın birinde yabanc1 cisim batması (kılç1k batması) sonrası, diğerinde diş ağrısı öyküsü geliştiği tarifleniyor, ancak ikisinde de kaynak olabilecek herhangi bir enfeksiyon odağ 1 saptanmadı.

Servikal nekrotizan fasiit hastalarında belirgin olarak WBC fazladır. Yüksek ateş görülür. Hastalarda oral alımın sorunlu olmasına bağlı olarak dehidrasyon ve malnutrisyon da görülmektedir. Hastada beslenme bozukluğu varsa dolaşımdaki lenfosit ve $\mathrm{T}$ hücre sayısı azalır. Ayrica bu hastalarda antikor yanit1 ve polimorfonükleer hücre fonksiyonu da bozulur. Bu değerlerdeki değişim enfeksiyona yeterli yanıtın verilememesine neden olurken, servikal nekrotizan fasiitin ilerlemesine de neden olur. Son y1llarda nekrotizan fasiit tedavisinde adjuvan tedavi olarak önerilen hiperbarik oksijen tedavisi, plazmada çözünmüş oksijen konsantrasyonunu ve arteriyel oksijen parsiyel basıncını artırarak tüm dokularda ve sıvılarda hiperoksi oluşturmakta ve lökositlerin bakterisidal etkilerini stimüle etmektedir. Ayrica, fibroblast replikasyonunu, kollagen sentezini ve neovaskülarizasyonu artırarak yara iyileşmesine olumlu etki göstermektedir. ${ }^{[7]}$ Nekrotizan fasiit oluşumunda risk faktörleri diabetes mellitus, malnutrisyon, obezite, ateroskleroz, şiddetli karaciğger hastalığ 1 ve AIDS’tir. ${ }^{[5]}$ Bizim olgularımız üçü bilinen diabetes mellitus hastası idi. Diabetes mellituslu hastalarda servikal nekrotizan fasiit, uzun hastanede kalı̧̧ süresi ve yüksek mortalite bildirilmiştir. ${ }^{[7,8]}$

Servikal nekrotizan fasiit genelde polimikrobiyal bir enfeksiyondur. ${ }^{[5,7,8]}$ Tedaviye başlarken geniş spektrumlu antimikrobiyal tedavi tercih edilmeli, daha sonra 
cerrahi örneğin kültür sonucuna göre uygun tedavi düzenlenmelidir. ${ }^{[8]}$ Olgularımızın tamamında geniş spektrumlu antibiyoterapi başlandı ve kültür sonucuna göre gerekli durumda tedavi revizyonu yapıldı. Üçüncü olgumuzda cerrahi materyal mucor düşündürmesi nedeniyle enfeksiyon kliniğinin görüşüne göre geniş spektrumlu antibiyoterapiye ek olarak antifungal (amfotericin) tedavisi başlandi.

Enfeksiyonun yaygınlığını ve hastanın hava yolunun değerlendirilebilmesi için radyolojik incelemeler vakit geçirmeden istenmelidir. Bu incelemeler; standart radyografik incelemeler veya BT olabilir. Olguların dördünün değerlendirilmesinde kontrastlı boyun BT kullanıldı, Olgu 3'de boyun manyetik rezonans görüntüleme kullanıldı. Olguların tamaminda solunum sikıntısı nedeni ile trakeotomi cerrahi sırasında eş zamanlı olarak açıldı.

Servikal nekrotizan fasiit standart tedavisi medikal tedavi ve acil cerrahi debridman olarak tanımlanmakta olup, hiberbarik oksijen tedavisi adjuvant terapi olarak önerilmektedir. ${ }^{[9]}$ Erken dönemde tüm fasyal planların açılarak ve yaygın nekrotik dokuların debridmanı yapılarak uygulanan cerrahi müdahale, tedavi sonuçlarında başarıyı getirirken, hastanede kalış süresini de azaltmaktadır. ${ }^{[8]}$ Yapilacak cerrahi müdahalenin gecikmesi mortalitenin artması açısından bir risk faktörüdür. ${ }^{[3,5]}$ Ayrıca son zamanlarda yapılan çalışmalar gözden geçirildiğinde, hiperbarik oksijen tedavisi kullanımının mortaliteyi, hastanede kalma süresini ve cerrahi debridman sayısını azalttığg ileri sürülmektedir. ${ }^{[9,10]}$ Olgularımızda cilt ve cilt alt1 yaygin nekroz alanları saptand 1 ktan hemen sonra cerrahi debridman yapıldı. Olgu 1'e ilk ameliyattan bir hafta sonra tekrar debridman yapıldı. Olgu 3 ilk ameliyattan 10 gün sonra tekrar cerrahi debridman için ameliyata alındı. Birinci, üçüncü ve dördüncü olgumuzda aynı zamanda mediastinit gelişmesi nedeniyle gögüs cerrahisi eşliğinde torakotomi yapilarak debride edildi. Kliniğimizde hiperbarik oksijen ünitesi bulunmadığından olgularımıza hiperbarik oksijen tedavisi öneremedik.

Sonuç olarak, servikal nekrotizan fasiit enfeksiyonları nadir görülür. Ancak agresif ve hızlı bir şekilde ilerleye- rek hayatı tehdit eden durumlara yol açabilir. Bu nedenle de cerrahi ve medikal tedaviye hızlıca başlanmalıdır.

\section{Çıkar çakışması beyanı}

Yazarlar bu yazının hazırlanması ve yayınlanması aşamasında herhangi bir çıkar çakışması olmadığını beyan etmişlerdir.

\section{Finansman}

Yazarlar bu yazının araştırma ve yazarlık sürecinde herhangi bir finansal destek almadıklarını beyan etmişlerdir.

\section{KAYNAKLAR}

1. Wilson B. Necrotizing fasciitis. Am Surg 1952;18:416-31.

2. Osma U, Eyigör $H$, Yılmaz MD. A fatal case of necrotizing fasciitis of the neck. [Article in Turkish] Kulak Burun Bogaz Ihtis Derg 2011;21:341-4.

3. Schiodt M. Deep cervical infections - an uncommon but significant problem. Oral Dis 2002;8:180-2.

4. Safran DB, Sullivan WG. Necrotizing fasciitis of the chest wall. Ann Thorac Surg 2001;72:1362-4.

5. Krenk L, Nielsen HU, Christensen ME. Necrotizing fasciitis in the head and neck region: an analysis of standard treatment effectiveness. Eur Arch Otorhinolaryngol 2007;264:917-22.

6. Fliss DM, Tovi F, Zirkin HJ. Necrotizing soft-tissue infections of dental origin. J Oral Maxillofac Surg 1990;48:1104-8.

7. Altın G, Orhan İ, Şanlı A, Aydın S, Bekmez ZE. Nekrotizan fasiitte adjuvant terapi olarak hiperbarik oksijen. Istanbul Med J 2014;15:193-5.

8. Tung-Yiu W, Jehn-Shyun H, Ching-Hung C, Hung-An C. Cervical necrotizing fasciitis of odontogenic origin: a report of 11 cases. J Oral Maxillofac Surg 2000;58:1347-52.

9. Cinc1k H. Effectiveness of hyperbaric oxygen therapy on deep neck ... of neck. Turkiye Klinikleri J E.N.T. Special Topics 2010;3:41-7.

10. Krenk L, Nielsen HU, Christensen ME. Necrotizing fasciitis in the head and neck region: an analysis of standard treatment effectiveness. Eur Arch Otorhinolaryngol 2007;264:917-22. 